\title{
First record of Marteilia parasite (Paramyxea) in zooplankton populations in a natural estuarine environment
}

\author{
Noèlia Carrasco ${ }^{1,4^{*}}$, Inmaculada López-Flores ${ }^{2}$, Miquel Alcaraz ${ }^{3}$, M. Dolores Furones ${ }^{1,4}$, \\ Franck C.J. Berthe ${ }^{5}$ and Isabelle Arzul ${ }^{2}$
}

\footnotetext{
${ }^{1}$ IRTA, St. Carles de la Ràpita, Tarragona, Spain

${ }^{2}$ Laboratoire de Génétique et Pathologie IFREMER, La Tremblade, France

${ }^{3}$ Institut de Ciències del Mar (CSIC), Barcelona, Catalonia, Spain

${ }^{4}$ Centre de Referència en Aqüicultura de Catalunya, CRAq, Spain

${ }^{5}$ Canada Research Chair in Aquatic Animal Health, Department of Pathology and Microbiology of Atlantic

Veterinary College, University of Edward Prince Island, Charlottetown, Canada
}

\author{
* Corresponding author: Noèlia Carrasco. Irta- Sant Carles de la Ràpita, P.O. Box 200, Ctra Poblenou \\ del Delta km 5, Sant Carles de la Ràpita 43540, Tarragona, Spain. \\ Telephone number 00-34-977745427, Fax number 00-34-977744138, e-mail address: \\ Noelia.Carrasco@irta.es
}

\begin{abstract}
:
The life cycle of the species forming the genus Marteilia (Phylum Paramyxea), which are marine protozoan parasites of molluscs, is still poorly known, although there are evidences of the need of intermediate hosts. Until now, only the calanoid copepod Acartia (Paracartia) grani has demonstrated being involved in the life cycle of the parasite infecting flat oysters growing in ponds. However, no complex natural environments such as bays or estuaries have been studied for this purpose. Herein, we conducted a survey of the presence of the protozoan Mateilia by PCR in the zooplankton community of a natural ecosystem, the Alfacs and Fangar bays in the Delta de l'Ebre (NW Mediterranean). Identification of zooplankton species found infected allowed us to propose two new Marteilia hosts: the Cyclopoida Oithona sp. and an undeterminated Harpaticoida species. This is the first report of Marteilia in Zooplankton species sampling in a natural enzootic area.
\end{abstract}

Key words: Marteilia, life cycle, mollusc parasite, Oithona sp., Harpaticoida sp., zooplancton 


\section{INTRODUCTION}

Species of the genus Marteilia are protozoan parasites belonging to the Phylum Paramyxea which affect commercially important bivalve species such as the mussels Mytilus galloprovincialis and M. edulis, and the European flat oyster Ostrea edulis (Grizel et al., 1974; Villalba et al., 1993; Fuentes et al., 2002). This parasite is responsible for a notifiable disease to the OIE (the World Organisation for Animal Health) (Anonymous, 2005).

The infection by Marteilia refringens was reported for the first time in Europe in 1968 in flat oysters Ostrea edulis in Aber Wrach, Brittany (Comps 1970) and nowadays its life cycle is still not clear. Previous studies described parasite dynamics in oysters, and showed that the transmission period of Marteilia refringens was from June to August, in Atlantic waters, when water temperatures is over $17^{\circ} \mathrm{C}$. During this period and these conditions, uninfected oysters can become infected by the parasite (Balouet 1977, Audemard et al. 2001). Several attempts of experimental direct horizontal transmission were carried out, reproducing temperature and salinity conditions of transmission period in natural environments, however no concluding results were obtained and the hypothesis of heterogenic life cycle was therefore postulated (Balouet 1977, Comps \& Joly 1980, Berthe et al. 1998). Recently, an intermediate host was identified for Marteilia refringens, (Audemard et al., 2002). In order to avoid the high biodiversity of natural environments such as bays and estuarine systems, the research of a possible intermediate host was carried out in a particular semi-closed natural pond (known as "claire"). In addition, the use of molecular tools instead of classical histological diagnostic methods facilitated the analysis for the detection of the parasite in potential hosts (Audemard et al. 2001; Audemard et al., 2002). Audemard and co-worker (2002) demonstrated that the copepod Acartia (Paracartia) grani is contiguous to Ostrea edulis in the life cycle of $M$. refringens. Working in "claires" facilitated the initial screening step of research for intermediate hosts because the biodiversity in these environments is about ten times lower than in estuaries and other semi-landlocked marine coastal areas. However, these results should be validated in more open and complex natural ecosystem (Audermard, 2002; Berthe, 2004) and Delta de l'Elbre bays constitute a site of interest for conducting such study.

On an other hand, in Europe, two Marteilia genetic groups were differentiated based on the sequence analysis of the intergenic spacers of ribosomal genes (rDNA) of the parasites. Marteilia refringens (or type "O") that usually infects flat oysters, and Marteilia maurini (or type "M") that usually infects mussels were differentiated based on rDNA ITS-1 sequences (Le Roux et al. 2001; Novoa et al., 2005), while analyses based on the rDNA IGS suggested that parasites infecting oysters and mussels constituted two different strains of one Marteilia species (Lopez-Flores 2004) and if the synonymy of M. refringens and M. maurini is upheld, the name $\mathrm{M}$. refringens would have the priority . Both parasite types "O" and "M" were experimentally transmitted from oysters and mussels respectively to copepods Acartia grani (Carrasco, 2005). However, infection patterns were different :parasites originating from mussels did not proliferate in copepods while parasites originating from oysters showed proliferation in copepod tissues. Furthermore, the transmission of the parasite from infected copepods to healthy flat oysters and mussels failed, as well as in previous studies (Berthe 2004), leaving open new perspectives of studying other species as intermediate hosts for Marteilia.

In this work, we conducted a survey about the presence of Marteilia sp. in the natural environment of the Ebre Delta bays, an enzootic area of marteiliosis, and more especially in zooplankton community.

\section{MATERIALS AND METHODS}

\subsection{Site of study}

The Ebre delta is located in the Northwestern Mediterranean sea (Fig 1). This delta is formed and drawn by sediments of the Ebre river and includes two semi-enclosed bays: Fangar Bay at the North and Alfacs Bay at the South. Both bays are exploited for mollusc aquaculture and fisheries. The Ebre Delta is the first Spanish shellfish production site on the Mediterranean coast. The production of bivalves is estimated to be more than 2600 metric tons per year (2004, www.gencat.net/darp). Major cultivated species are mussels, Mytilus galloprovincialis (1700 tn/year), Pacific oysters, Crassostrea gigas (854 tn/year) and Japanese carpet clams, Ruditapes phillipinarum (94 tn/year). In the past, the culture of the European flat oyster, Ostrea edulis, was also carried out in the Ebre delta bays, but several mortality outbreaks in the 90s 
have led farmers to substitute this specie by $C$. gigas. Nowadays, only experimental ropes of $O$. edulis are present in the bays in punctual periods. Oyster and mussel culture is traditionally achieved on ropes tied on wood frames (rafts) also called "bateas".

\subsection{Zooplankton sampling and treatment}

Zooplankton was sampled in both bays in the vicinity of the mussel rafts by means of horizontal net hauls made with a Juday-Bogorov net fitted with $100 \mu \mathrm{m}$-mesh. Samples collected in both bays were fixed in $95 \%$ ethanol for further analyses. One part of each sample was used for DNA extraction. Zooplankton counting and species identification was carried out under stereomicroscope (Nikon SMZ800). Individuals from dominant species present in zooplankton samples found infected by Marteilia were sorted and selected for further molecular analyses.

An initial sampling (one sample from Alfacs bay and one sample from Fangar Bay) of zooplankton was performed in October 2003 , as a first preliminary analysis. Then, a sampling was performed every two weeks from June to August 2004, with some extra samples taken in October of the same year. A total of 9 samples were obtained from each bay.

\subsection{DNA extraction and amplification by PCR}

DNA extraction was carried out as follows: ethanol-fixed animals were ground and suspended in 10 volumes of extraction buffer $(\mathrm{NaCl} 100 \mathrm{mM}, 10 \mathrm{mM}$ Tris pH 8, $25 \mathrm{mM}$ EDTA pH 8, SDS $0,5 \%)$ containing proteinase $\mathrm{K}(100 \mu \mathrm{g} / \mathrm{ml})$. Following an overnight incubation at $55^{\circ} \mathrm{C}$, DNA was extracted using a standard protocol involving phenol/chloroform, and precipitation with ethanol. Integrity and quantity of DNA were measured by spectrophotometry.

Two PCR protocols previously described were used for the detection of Marteilia in samples of zooplankton. The first one is a simple PCR using primers pr4/pr5 and amplifies a 411 bp fragment of the 18S rDNA and ITS1 (Le Roux et al., 2001). The second one is a nested PCR using successively primer pairs MT1/MT2 and MT1B-MT2B and amplifies, at the end, a $358 \mathrm{bp}$ fragment of the intergenic spacer of ribosomal genes IGS (López-Flores et al., 2004).

PCR analyses were performed as previously published (Le Roux et al., 2001. López-Flores et al., 2004). For each analysis, DNA extracted from an infected oyster was used as a positive control and what about negative controls???

Pr4/pr5 amplified products showing an expected size of 411 bp were cloned using the pCR 2.1 Vector System (Invitrogen, Groningen, Netherlands). X recombinant clones were selected for PCR-RFLP analysis using Pr4 /Pr5 primers and the restriction enzyme Hha1 (Promega) in order to determinate the genetic type of the parasite (Le Roux et al., 2001). Resulting restriction fragments were analyzed electrophoretically on $2 \%$ agarose gels.

\section{RESULTS}

Firstly speak about species and abundance found in each zooplankton sampling

In a first step, PCR analyses for Marteilia detection were performed using DNA extracted from bulk zooplankton samples. Afterwards, zooplankton species were identified and sorted by microscopical examination of positive samples, and PCR analysis was then realised separately for every of these species in order to identify putative Marteilia hosts.

The primers Pr4 and Pr5 amplified products of expected size in one sample from Fangar Bay collected in 2003. PCR-RFLP analysis identified the parasite present in the sample as Marteilia type "M" for all the studied amplicons how many???(Fig. 3A). No amplification could be obtained neither for the sample from Alfacs Bay collected in 2003 nor for the samples collected in 2004 in both bays (18 samples). Morphological examination of the zooplankton species present in this positive sample showed that the Calanoid copepod Acartia latisetosa, the Cyclopoid Oithona sp. and an indeterminate Harpaticoid species were the most represented taxa. No amplification was obtained when the PCR analysis was performed using DNA extracted from each of these three identified and sorted species.

Nested-PCR using MT primers allowed to obtain amplified products of 358 bp in 8 samples including one of the 9 samples collected in 2004 in Alfacs bay, the unique sample realised in 2003 in Fangar bay and 6 of the 9 samples collected from this last place in 2004 (Fig. 3B and 4). Nested-PCR analysis could only be performed on species sorted from sample collected in 
2003 in Fangar bay. These tests allowed the detection of Marteilia in the Cyclopoid Oithona sp. and an undetermined Harpaticoid species from Fangar Bay (Fig. 3C).

You need to re write this section "Results". I suggest 4 paragraphes

- First give results about the different species of zooplankton present in the different samples and their respective abundances according to the different bays (differences?) and to the period

- Then present DNA extraction results for all your samples : quality and quantity (later in the discussion, it will help you to explain why you had so few PCR results especially for the species once sorted)

- You can then give results of PCR using PR4/PR5 on total zooplankton sample and separated species plus the results from the digestion ( $X$ clones selected, $x$ with type $M$ and y with type O)

- Similarly present results of nested PCR (using primers MT) on on total zooplankton sample and separated species 


\section{DISCUSSION}

Claire ponds, in which previous studies on Marteilia life cycle have been developed, are selective ecosystems by decreasing biodiversity and high environmental fluctuations. For this reason, studies on Marteilia life cycle in more open and complex ecosystems are required to validate and complete results obtained in the "claire" system (Audermard, 2004). Delta de l'Elbre constitutes a site of interest for such study because of the presence of the disease and the production of host species like Mytilus galloprovincialis and Ostrea edulis. Moreover environmental data and data related to zooplankton species are already available for this particular site (references...).

You need to include a small paragraph on types $\mathrm{O}$ and $\mathrm{M}$ and to give previous results obtained for mussels and oysters from both bays. Until now, limitations of diagnostic techniques have been an important handicap in the protozoan life cycle researches. Development of molecular techniques has improved detection and knowledge on these parasites including Marteilia refringens for which a copepod, Acartia grani, could be identified as a potential intermediate host (Le Roux et al. 1999, Le Roux et al. 2001, Audemard et al. 2004). Moreover, a PCR-RFLP technique (Le Roux et al., 2001) has been developed allowing the discrimination of two types: "O" which is supposed to infect more often oysters and "M" mussels. A nested PCR targeting a fragment of the IGS was developed more recently (Lopez-Flores et al., 2004) and was used in addition to the PCR RFLP in the present study for the detection of Marteilia in zooplankton samples. Important differences were observed between results obtained by both, ITS-1 and IGS, diagnostic techniques. Pr4/pr5 primers allowed the detection of the parasite in a unique sample, collected in 2003 in Fangar bay while 8 samples appeared infected when tested by nested PCR.

Here you need to speak about the quality and quantity of extracted DNA and the difference of sensitivity of both PCR techniques.

Then you have to discuss about the detection of the parasite in zooplankton according to the season or period and you have to link this result with those you already obtained in mussels and oysters from both bays in previous study. You also have to disvuss about the different species present in these positive samples (always the same or not?)

PCR RFLP revealed that the unique sample found infected when using pr4/Pr5 primer pair was infected by Marteilia type "M".

All samples found positive by PCR were examined under a microscope for species identification and to sort individuals from most abundant species. Three different groups of individuals selected from Fangar bay in 2003 showed positive results when tested by nested PCR: Oithona sp. and an indeterminate Harpaticoid species. Unfortunately, zooplankton was very scarce in the samples collected during 2004. Only copepodites of indeterminate species and very few individuals (1 to 4) of Acartia latisetosa and A. grani could be separated from positive samples,

The presumable implication of the zooplankton community in the Marteilia life cycle in complex estuarine environments is hypothetised for several reasons. For me the implication is not so obvious

The time chosen for sampling coincided with critical outbreak periods for the parasite: during 2003, zooplankton was sampled one and half month after massive mussel mortalities that took place in summer of 2003 due to high temperature of the water (up to $29^{\circ} \mathrm{C}$ ) during several weeks (Carrasco, unplublished results); and during 2004, the sampling was carried out during the critical period for Marteilia spp. transmission as observed by (Balouet 1977, Audemard et al. 2001). Marteilia was detected in mussels of Delta de l'Ebre bays in 2003 (Carrasco, unpublished results) before the episode of massive mussel mortality in the bays (in both bays???) Only one sample of zooplankton collected in October 2003 was found positive in Fangar bay and PCR-RFLP results on this sample showed that zooplankton was parasitized by the mussel profile while no mussels were alive in the bay. Marteilia propagules released to the environment have presumably short-life (Berthe, 2004). Most of copepoda species have a life cycle of around one month (Alcaraz, personal communication). Zooplankton species could play a role of dispersion of the parasite, horizontal or vertical transmission between them, and a role of intermediate host transmitting the parasite between bivalves. Zooplankton community could thus act as a reservoir of the parasite in extreme ecological situations and ensure the continuity of the parasite. 
Your results are biased because of the difficulty to select a lot of individuals from a species. Thus you have to introduce this paragraph by saying that probably more species are infected. You can also suggest other sampling approach to solve this problem and remind that PCR result is not enough and needs to be completed by other techniques like in situ hybridization, TEM.

Marteilia was detected in two new zooplanctonic hosts, Oithona sp. and indeterminate Harpaticoid specie. This result did not confirm results obtained in the "claire" model, where Acartia grani was the most abundant copepod species infected by Marteilia. However, other zooplanctonic species such as an indeterminate group of Cyclopoida were already reported positive in the "claire" model (Audermard, 2002). Although the recurrent detection of Marteilia in $A$. grani,the rare detection of the parasite in this species, was considered related to feeding activity more than to parasitation. Because of the failed attempts of transmitting Marteilia from A.grani to healthy bivalves, as well as Audermard and co-workers (2002), we propose to have in consideration the more detailed study of the roll of the new proposed hosts in the life cycle of Marteilia parasite. Furthermore, a more accurate study, including the use of the new IGS molecular tools, of the dynamics of this parasite in the zooplankton community, as well as in bivalve populations in the bay, will provide new insights in the research of potential intermediate hosts for Marteilia and to clarify its life cycle.

The detection of Marteilia on the zooplankton populations belonging to a complex natural environment such as the Delta de l'Ebre bays open new perspectives for further Marteilia life cycle studies.

\section{Acknowledgements}

This study was supported by founds from INIA pre-doctoral grand provided by Spanish Minister of Science, the MCYT Project CTM-02575/MAR to M.A., the EU Community Reference Laboratory for Mollusc Diseases and Technology, and the Marie Curie Host Fellowships (n05865H/P297815F) provided by the European Commission. We would like to thank Dr. Renault and Dr. Goulletquer for the invitation and welcome in the Laboratory of Genetics and Pathology of Molluscs of IFREMER (La Tremblade, France). We would like to thank the CRAq funds from the Molluscs project coordinated by Dra. Ramon (IRTA). We would like also to thanks Jesús Carles (CADEMAR) for providing bivalve culture material and facilities and Olga Bellot, Noèlia Gras, Mireia Camps and Marta González for technical work. Also to thank Josep $M^{a}$ Reverté and Miquel Rosales for collecting samples.

\section{References}

Alcaraz, M., Wagensberg, M. (1977). Application de l'analyse des séries temporales à l'étude de la relation entre la proportion sexuelle et la densité des populations en copépodes. ICES, C.M. 1977/ L: 12, 5pp.

Anonymous, 2005. Aquatic Animal Health Code, $8^{\text {th }}$ Edition. Office Internationale des Epizooties, Paris.

Armengol, J., Alonso, M., Alcaraz, M. (1988). Els Copèpods. A: Història Natural dels Paisos Catalans. Vol. 6. Editat per J. ARMENGOL. Enciclopèdia Catalana.

Audemard C, Barnaud A, Collins CM, Le Roux F, Sauriau PG, Coustau C, Blachier P, Berthe FCJ (2001) Claire ponds as an experimental model for Marteilia refringens life-cycle studies: new perspectives. Journal of Experimental Marine Biology and Ecology 257:87108

Audemard C, Le Roux, F., Barnaud, A., Collins, C., Sautour, B., Sauriau, P-G, De Montaudouin, X., Coustau, C., Combes, C., Berthe, F. (2002) Needle in a haystack: involvement of the copepoda Paracartia grani in the life-cycle of the oyster pathogen Marteilia refringens. Parasitology 124:315-323

Balouet G (1977) Marteilia refringens --considerations of the life cycle and development of Abers disease in Ostrea edulis. Int. Symp. Haplosporidian and Haplosporidian-like Diseases of Shellfish; Gloucester Point, VA (USA); 17 Aug 1977. In : Haplosporidian 
and Haplosporidian like diseases of shellfish. An international symposium held at the Virginia Institute of Marine Science, Gloucester Point, VA 41:64-66

Berthe F, Le Roux, F., Adlard, RD., Figueras, A. (2004) Marteiliosis in molluscs: A review. Aquatic Living Resources 17:433-448

Berthe FCJ, Pernas M, Zerabib M, Haffner P, Thebault A, Figueras AJ (1998) Experimental transmission of Marteilia refringens with special consideration of its life cycle. Diseases of Aquatic Organisms 34:135-144

Carrasco N, Arzul, I.,Furones, D., Chollet, B., Robert, M., Joly, J. P. and Berthe, F. (2005) Comparative experimental infection of Marteilia spp. from mussels and oysters in the copepod Paracartia grani. 12th EAFP International Conference on Diseases of Fish and Shellfish, Copenhagen, Denmark, p P- 206

Comps M (1970) Observations sur les causes d'une mortalité anormal des huîtres plates dans le bassin de Marennes. Rev. Trav. Inst. Peches Marit. 34:317-326

Comps M, Joly JP (1980) [Experimental contamination of Mytilus galloprovinicialis Lmk by Marteilia refringens ]. Sci. Peche:19-21

Fuentes, J., López, J.L., Mosquera, E., Vázquez, J., Villalba, A., Álvarez, G., 2002. Growth, mortality, pathological conditions and protein expresión of Mytilus edulis and $M$. galloprovincialis crosses cultured in the Ría de Arousa (NW of Spain). Aquaculture 213, 233-251.

Grizel, H., Comps, M., Bonami, J., Cousserans, F., Duthoit, J., Le Pennec, M., 1974. Recherche sur l'agent de la maladie de la glande digestive de Ostrea edulis Linnè. Bull. Inst. Pêches Marit. 240, 7-30.

Le Roux F, Audemard C, Barnaud A, Berthe F (1999) DNA Probes As Potential Tools for the Detection of Marteilia refringens. Marine Biotechnology 1:588-597

Le Roux F, Lorenzo G, Peyret P, Audemard C, Figueras A, Vivares C, Gouy M, Berthe F (2001) Molecular Evidence for the Existence of Two Species of Marteilia in Europe. Journal of Eukaryotic Microbiology 48:449-454

Lopez-Flores I, de la Herran, R., Garrido-Ramos, MA., Navas, JI., Ruiz-Rejon, C., Ruiz-Rejon, M. (2004) The molecular diagnosis of Marteilia refringens and differentiation between Marteilia strains infecting oysters and mussels based on the rDNA IGS sequence. Parasitology 129:411-419

Novoa, B., Posada, D., Figueras, A., 2005. Polymorphisms in the sequences of Marteilia internal transcribed spacer region of the ribosomal RNA genes (ITS-1) in Spain: genetic types are not related with bivalve hosts. J. Fish Dis. 28, 331-338.

Villalba, A., Mourelle, S.G., Lopez, M.C., Carballal, M.J., Azevedo, C., 1993. Marteiliasis affecting cultured mussels Mytilus galloprovincialis of Galicia (NW Spain). I. Etiology, phases of the infection and temporal and spatial variability in prevalence. Dis. Aquat. Org. $16,61-72$. 


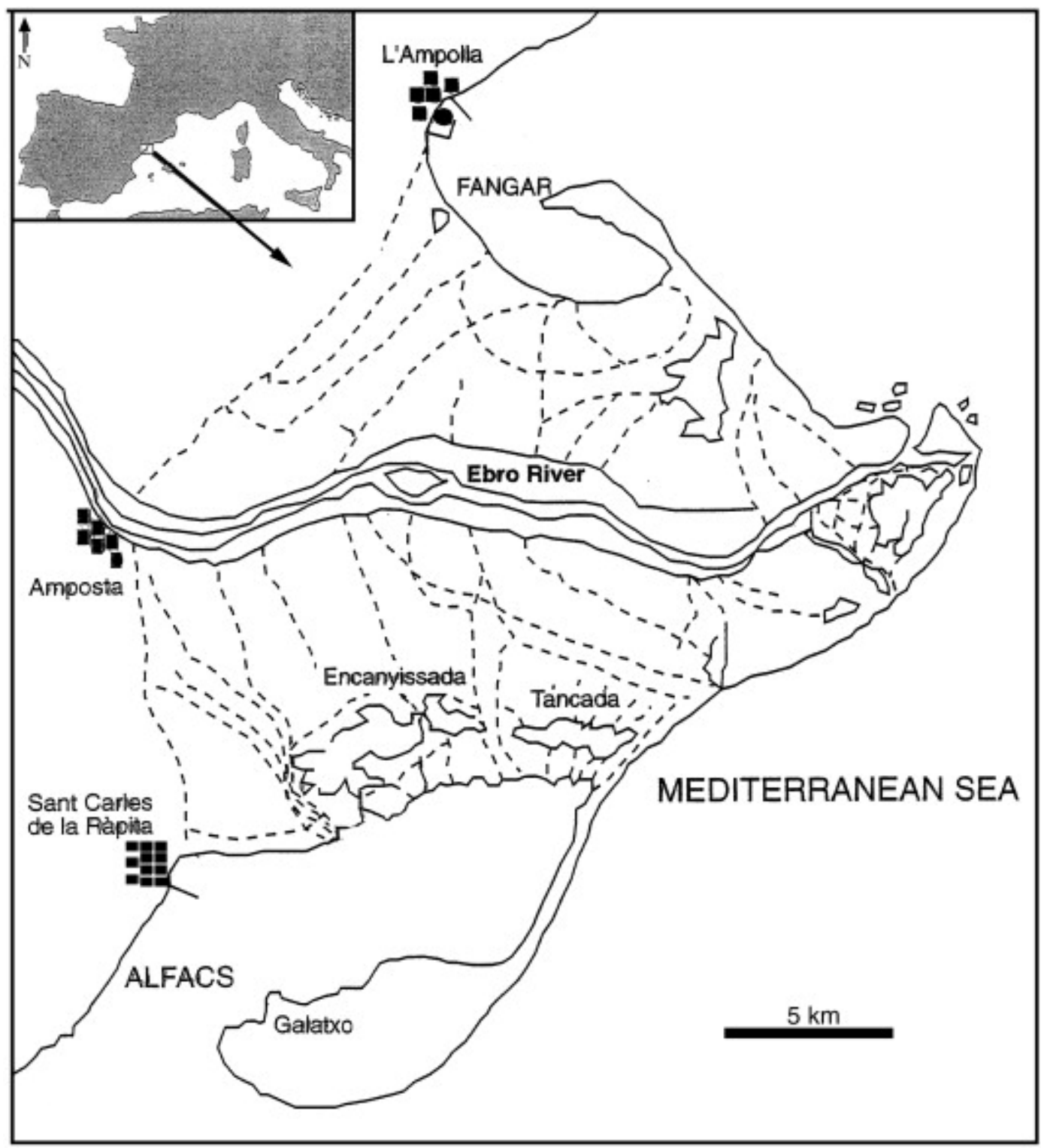

Fig. 1. Study site: Delta de l'Ebre, Catalonian coast, North East of Spain 


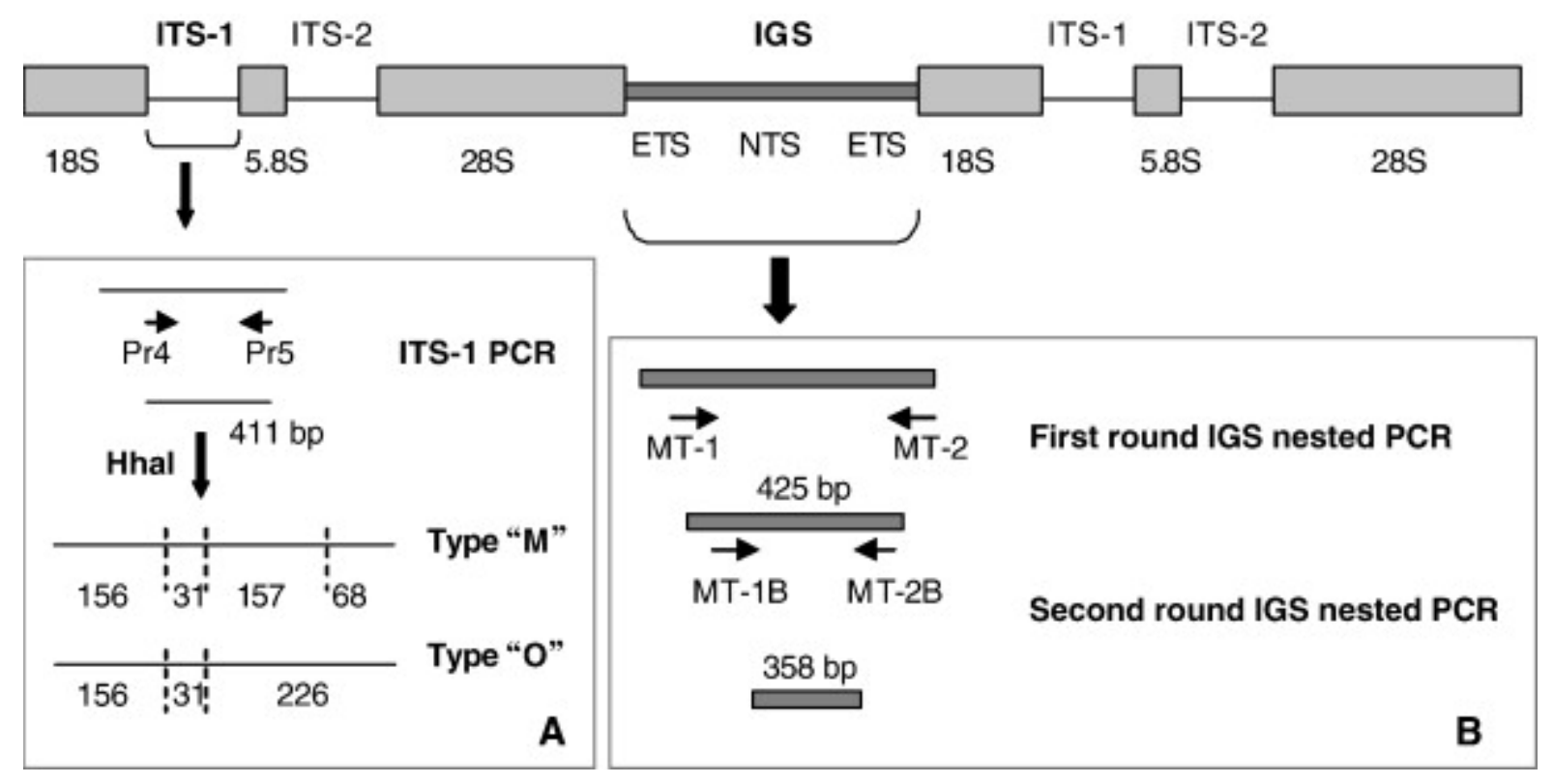

Fig. 2. Schematic representation of the nuclear ribosomal DNA repeating unit and location of the ITS-1 and the IGS regions. ITS, internal-transcribed spacer; IGS, intergenic spacer; ETS, external-transcribed spacer; NTS, non transcribed spacer. (A) ITS-1 PCR primers location and Hhal restriction sites for both, Marteilia type "M" and type "O". (B) Location of the primers of IGS nested PCR.

(A)

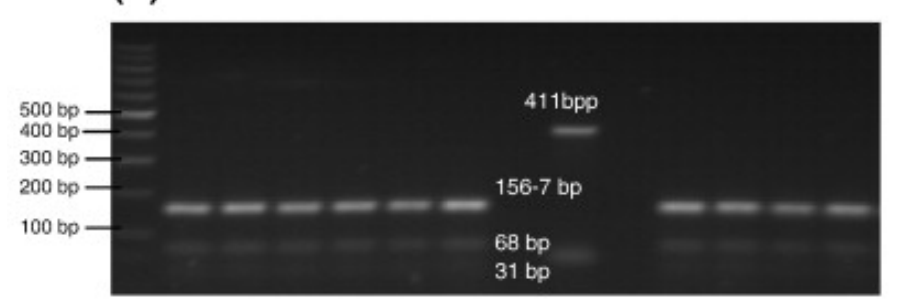

(B)

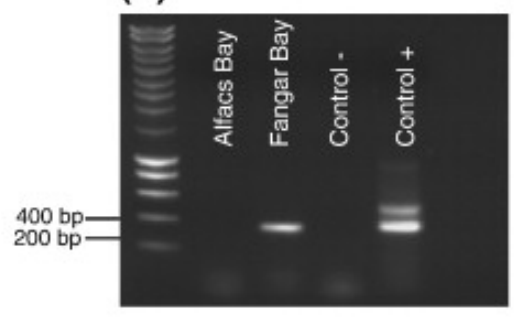

(C)

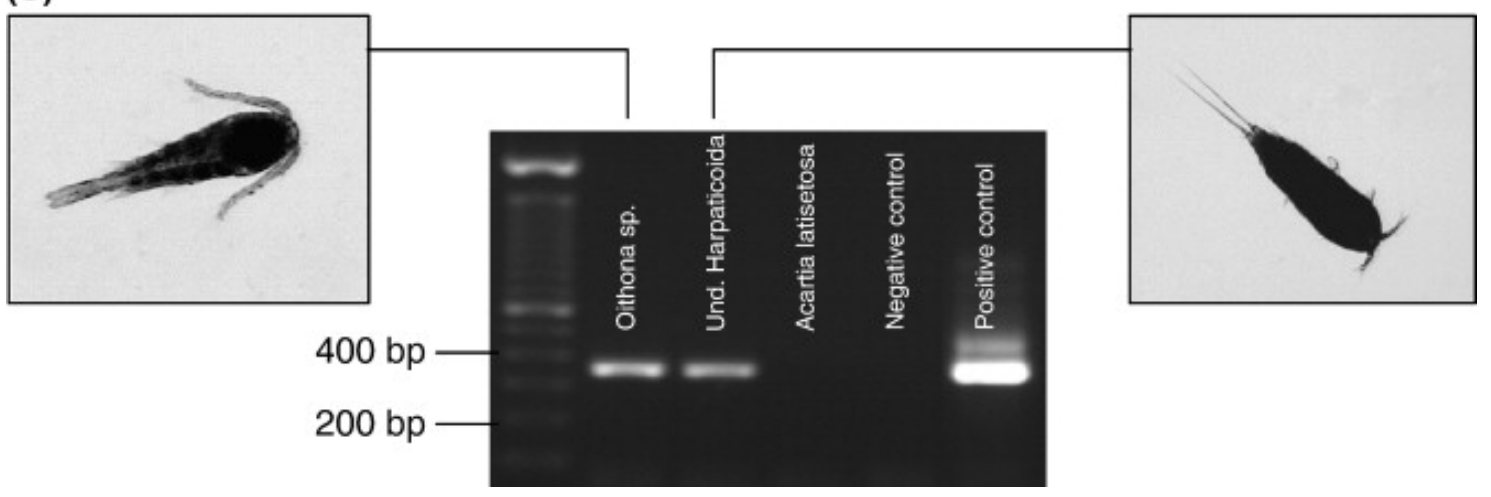

Fig. 3. Detection of Marteilia by PCR based on ITS-1 and IGS sequences in 2003 zooplankton samples. (A) PCR-RFLP analysis of the ITS-1 sequence amplified from one sample of zooplankton from Fangar Bay. The $411 \mathrm{bp}$ amplified fragment yielded the observed fragment after digestion with Hhal (fragments of 156-157 bp, $68 \mathrm{bp}$ and $31 \mathrm{bp}$ ). (B) PCR analysis of the IGS sequence in zooplankton. Panel (C) show PCR analysis of IGS sequence in zooplankton separate species from Fangar Bay. 


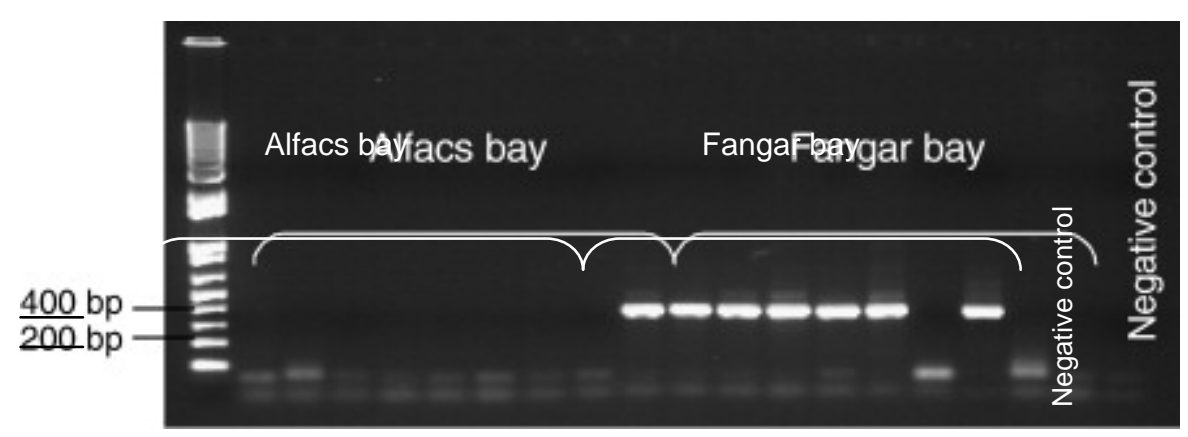

Fig. 4. Results for Marteilia IGS nested PCR (amplifying a fragment of 358 bases pairs) analyses on 2004 zooplankton communities in Alfacs and Fangar bays, in the Delta de l' Ebre. 